\title{
LOCAL FOOD SYSTEMS SUPPORTED BY COMMUNITIES NATIONALLY AND INTERNATIONALLY
}

\author{
Izabella Mária BAKOS
}

\author{
${ }^{a}$ Szent Istvan University, Faculty of Economic and Social Sciences, H-2100 Gödöllö, Páter K. Str. 1., \\ bakosizabella89@gmail.com
}

Cite this article: Bakos, I. (2017). Local Food Systems Supported by Communities Nationally and Internationally. Deturope: Deturope, 9, 1: 59-79

\begin{abstract}
Due to the concerns about the long-term sustainability of globalized retail trade as well as the more and more determining health-conscious food-consuming attitude the systems of government respectively the groups of conscious consumers all over the world put emphasis on the popularization and development of local food chains and small-scale supply chains simultaneously they connect the retailers producing highquality, local foods with the direct markets. In my study, I would like to present an overview of the development and current state of community supported agricultural systems on the international and Hungarian level and on the basis of the results of my questionnaire survey. I will indicate whether there are any demand for local food in Hungary and about how much the population of the six investigated settlements are familiar with it. Within this type of alternative local food systems, farmers and their buyers form a community based on social capital (co-operation, mutual trust and mutual responsibility), a direct sales channel, in such a way that cooperation is also beneficial to the producer and the consumer. The producer is in an advantageous position as he can form a direct and long-term relationship with his consumers selling his high-quality products locally consequently he can work in a cost-effective and optimal way. However, the advantage of the consumer is that he can obtain healthy foods from reliable sources contributing to the maintenance of his health respectively to the development of local economy.
\end{abstract}

Keywords: agriculture supported by communities, buyer communities, communal farms, box systems

\section{INTRODUCTION}

These days the industrialized food supply chains are not sustainable in the long run, they do not contribute to the development of the local economies and the unity, wealth, identity, as well as the maintenance of the local values of local communities or to the environmental protection and maintenance of agricultural employment rate, consequently to the preservation of the classical characteristics of the countryside, either. The present intensive, industrial, and conventional food production started in the second half of the 20th century all over the world making the lives of farmers impossible. The retails are not competitive compared with the industrialized agriculture, globalized food trade as well as with the significantly changed consumer trends (Réthy and Dezsény, 2013). As opposed to the preference of the origin and nutrition value of foods and that of the local characteristics respectively the high-quality, nutritious food the mass consumption prevails. Today it is most important that every product should be available in the same place independently of the season, preferably at a low price 
and in a semi-prepared state. Generalization is not the right thing to do and I would like to avoid it but based on the empirical researches it is obvious that we can talk about a current set of problems whose multiplicative and negative effects should not be neglected. A radical change of paradigm is required by the consumers as well as in the respect of the reconsideration of food supply chains.

The international literature dealing with agricultural and food business practices pay special attention to alternative solutions, such as the food production activities of the population, consumer communities, community-supported agriculture, urban food councils, local food systems, school programmes hosted by farms, etc. (See Cooley-Las 1998, DeLind, 1999, Lamine, 2005, Mariola, 2008). These short food supply chains offer alternative opportunities for those who want to engage in conscious production and conscious consumer behaviour and support the local economy.

The current rural development policy of the European Union puts great emphasis on the supporting primary producers and small producers, the promotion of local food and the strengthening of the short supply chain type of distribution channels. In Hungary, the demand for developing and improving a network of short supply chains, both from the supply- and demand sides, has increased, so in the 2014-2020 Rural Development Program Hungary has developed the Short Supply Chain Thematic Program (REL), in which 3.84 billion forints can be used for these initiatives. In order to create viable, small-scale food systems, I think it is essential to examine consumers' attitudes, preferences and general consumer behaviour on local food. In this paper, I summarize the most important results of this questionnaire survey, which provide support for decision makers and local food system organizers as well.

\section{OBJECTIVES AND METHODS}

In my present study I intend to review the history of development and the present situation of agricultural systems supported by communities at national and international scales based on secondary research and document analysis method.

By conducting questionnaire surveys, I also examined the attitude towards local food, as well as the general food buying and consuming behaviour among the population of six Hungarian settlements. When selecting the sample areas, it was important to conduct the survey in settlements where there is already an alternative type of community-supported local food system, the bottom-up consumer-producer communities. My goal was to analyse various settlement types and demographic groups. I conducted the survey in the following six settlements, with the aid of second-year Agrobusiness and Rural Development Engineering students from the Szent István University: Esztergom, Kecskemét, Érd, Csömör (Spring 2016), Miskolc and Eger (Spring 2017). The method of sampling was arbitrary, but it was 
considered an important factor to make the questionnaire representative. The number of respondents providing valid data is 817 , of which $63.0 \%$ are women and $37.0 \%$ are men. $27.6 \%$ of the respondents were from Csömör, 21.2\% from Kecskemét, 16.3\% from Esztergom, 14.4\% from Miskolc, 12.2\% from Érd and 8.2\% from Eger. The sample is very mixed, based on the fact that group varied much according to their age, school education, occupation and income level. To process the questionnaire database, I used the statistical program package IBM SPSS Statistics 20.

When processing the results, besides the general description, I tried to discover the dependency relationships between the different criteria by using cross-table analysis. According to $\mathrm{HO}$ there is no correlation between the variables in the study. If H0 was discarded during the test, significant relationship was identified. The existence of the relationship is tested by the Pearson Chi-square. If the significance level of the indicator (Asymp.Sig. (2-sided) is below $0.05 \%$ (which is a typical significance level in the field of social sciences), there is a correlation between the variables examined (Sajtos-Mitev, 2007). The following association coefficients were used in order to examine the strength of the relationship: Cramer's V, Gamma and Eta indicators. The strength of the relationship was interpreted as follows:

- 0 to 0.199: weak connection

- 0.200 to 0.399 : moderately strong

- 0.400 -: strong connection.

\section{RESULTS}

\section{The history of the development of agriculture supported by the communities}

\section{$\underline{\text { International scale }}$}

The so-called CSA-type (Community Supported Agriculture) movements were launched in Japan and Europe in the second half of the $20^{\text {th }}$ century independently of each other. The first CSA-type communities appeared in Germany in the 1950s. Based on Rudolf Steiner's activity respectively his biodynamical agricultural system and social aspect the forming German communities promoted the creation of a natural and ecological type of farming. They provided areas of lands to biodynamical farmers who, in return, sold their products to them. During the 1970s the system showed significant development and the members could purchase lands that they rented out to farmers at affordable prices supplying them loans at the beginning of the seasons to cover their costs. This model became widespread in Switzerland and the leader of the movement there named Jan Van der Tuin imported and introduced the practice of communal farming in the USA as well. In the 1980s similar types of farms 
appeared in the USA and the worldwide spread equivalent of CSA called "Community Supported Agriculture" is supposed to have been born there. (Réthy-Dezsény, 2013) According to the determination of a community named Farm to City (n.d.) in Philadelphia the CSA can be regarded as a mutually favorable agreement between the community members and the local farmers according to which the farmers guarantee products during the season for the money payments made before the season. Each week of the season the farmers do the harvest and distribute them among the "share-holders", typically the members of CSA. In the majority of CSAs the so-called "boxes" delivered every week content the same things for each member. In case of some CSAs the members select the things that they want from a list every week. This is the equivalent of the methods applied by the buying communities. The producers deliver their foods to the premises determined by the members or they can be taken over at the farms. As the members of the CSAs pay for the foods at the beginning of the seasons they can share the advantages and risks with the farmers the level of which may differ depending on the weather conditions of the year. There have been many examples for the food-autonomy in the history of humankind, see the mayors in the medieval ages or the Soviet type farmers' co-operatives. For example, in Cuba all the institutions are obliged to be selfsufficient with food so the companies and schools have their own farms or gardens. These examples, however, are far from the agriculture supported by communities. The modern, present form of CSA derives from Japan. In 1971 Teruo Ichiraku, a philosopher, the leader of farmers' co-operatives drew the attention of the Japanese consumers to the dangers of chemicals used in agriculture and he took measures to launch the movement of ecological agriculture. Three years later the movement became real in the frame of the first Teikei project ("Food supplied with the face of the farmer") thanks to the co-operation of the enthusiastic housewives and farmers (Henderson, 2010). The Japanese Organic Agriculture Association - JOAA founded in 1971 described the "Teikei" as an idea to create an alternative way of distribution that is independent of the conventional markets (in. URGENCI). The manifestations of Teikei may vary but they share the characteristic in common that they are all direct distributing systems. For the sake of the formation and operation of Teikei systems the farmers and consumers have to create close relationships and hold meetings based on mutual understanding. Both parties ensure the work power and capital to support their own transport system. The Teikei is not only a practical idea but a dynamical philosophy to make people consider their lives better through their relationships either as a consumer or as a producer (URGENCI).

The center of the world organization of CSA is located in the little town of Aubagne in South France. The international top organization named "The International Network for Community Supported Agriculture (URGENCI)" started to spread the concept of communal 
farming that was popular in France in ten Middle-European countries and in North Africa in 2008 (Perényi-Horváth, 2009). Now the activity of the organization is present in several parts of Africa, Asia, Europe, the Middle-East, North- America and Latin-America. All over the world there seem to be an ever-growing interest for local foods and the farmers along with consumers form different communities and local food systems. The nominations of the initiatives and forms of manifestation may vary from country to country (Tab. 1), but they have the main characteristics in common.

Table 1 The names of Agriculture Supported by the Communities in some parts of the world

\begin{tabular}{|c|c|c|}
\hline Nomination & Original name & Abbreviation \\
\hline$U S A$ and $U K$ & $\begin{array}{l}\text { Community } \quad \text { Supported } \\
\text { Agriculture }\end{array}$ & CSA \\
\hline Canada/Québec & $\begin{array}{l}\text { Agriculture Soutenue par la } \\
\text { Communauté }\end{array}$ & ASC \\
\hline Japan & Teikei & 提携 \\
\hline Belgium & $\begin{array}{l}\text { Groupes d'achat solidaire de } \\
\text { l'Agriculture paysanne }\end{array}$ & GASAP \\
\hline Bulgaria & Съпричастно земеделие & - \\
\hline France & $\begin{array}{l}\text { Association pour le maintien } \\
\text { d'une agriculture paysanne }\end{array}$ & AMAP \\
\hline Croatia & Grupa solidarne razmjene & GSR \\
\hline Hungary & $\begin{array}{ll}\text { Közösség által } & \text { támogatott } \\
\text { mezőgazdaság, } & \text { Közösségi } \\
\text { mezőgazdaság } & \end{array}$ & - \\
\hline Germany & Solidarische Landwirtschaft & - \\
\hline Italy & Gruppi di Acquisto Solidale & GAS \\
\hline Portugal & Reciproco & - \\
\hline Romania & $\begin{array}{l}\text { Asociația pentru Susținerea } \\
\text { Agriculturii Țărănești }\end{array}$ & ASAT \\
\hline Switzerland & $\begin{array}{l}\text { Fédération romande } \\
\text { d'agriculture contractuelle de } \\
\text { proximité }\end{array}$ & FRACP \\
\hline
\end{tabular}

Source: on the basis of http://urgenci.net/, my own edition

The active civils are committed to their local farms sharing with them the advantages and risks of ecological farming. In the past century due to the development the relationship between humans and food-producing lands broke up. During the decades of free trade the family farms got into trouble. However, the several cases of food scandal-illnesses caused by food bacteria, the dairy and other products polluted by GMO and other chemicals- related to the import products- deriving from industrial production resulted in a crisis of no confidence (Henderson, 2010). The CSA means a return to a small-scale and direct direction of food supply that is favorable for the consumer, the producer and the environment as well.

Nowadays the Japanese CSA model has become well-known and followed all around the world. The agriculture supported by communities is present in four continents of the World. 
Tab. 2 shows the spatial distribution of the number of groups, consumers and farms based on the estimated data of URGENCI. At world scale the Farm Fresh To You can be considered as one of the biggest CSA communities counting 13.000 members.

Table 2 The estimated data of the Community Supported Agriculture in the world*

\begin{tabular}{|l|r|r|r|}
\hline \multicolumn{1}{|c|}{ Nomination } & Groups (pcs) & Consumers (head) & Farms (number) \\
\hline NORTH AMERICA & 7103 & 409700 & 7100 \\
\hline United States of America & 7000 & 400000 & 7000 \\
\hline Canada (Québec) & 103 & 9700 & 100 \\
\hline EUROPE & 3547 & 412580 & 4257 \\
\hline France & 1600 & 180000 & 3000 \\
\hline Italy & 1000 & 100000 & 700 \\
\hline England & 140 & 24000 & 100 \\
\hline Germany & 80 & 16000 & 80 \\
\hline Eastern-Europe & 51 & 3600 & 51 \\
countries) & & & 38 \\
\hline Switzerland & 38 & 7030 & 30 \\
\hline Spain (Basque Country) & 30 & 100 & 1877 \\
\hline ASIA & 1515 & 176650 & 700 \\
\hline Japan & 1000 & 100000 & 500 \\
\hline China & 500 & 75000 & 100 \\
\hline Korea & 10 & 1000 & 576 \\
\hline India & 4 & 600 & 35 \\
\hline AFRICA & 9 & 543 & \\
\hline *The given data of the continents and countries are estimated ones and they are not & & & \\
\hline
\end{tabular}

Source: based on Parot (2015), my own edition

\section{The European situation}

The first CSA was founded in 1978 in Switzerland, near Geneva (Les Jardins de Cocagne). In the 1970s and 1980s only few similar initiatives were launched in Europe, however, after 2000 this type of movement became more and more popular. As defined in the regulation of 834/2007/EK of the European Council on the ecological farming: " the ecological farming is a system consisting of economic management and food-production that involves the best environmental protection practices, the high-quality biodiversity, the preservation of natural resources, the application of animal welfare standards at a high level, and certain producing methods that agree with the preferences of given consumers to products made of natural ingredients and produced in natural ways. The ecological production has a double social role: on the one hand, it supplies a special market that satisfies the need of the consumers for ecological products; on the other hand, it produces common goods that can significantly contribute to the environmental protection and animal welfare as well as to the rural development."

As the map shows (Fig. 1), nowadays this environmentally and socially sustainable type of alternative farming is present in the majority of the European countries. Countries in which CSAs operate are shown in dark green color based on surveys of 2015. 
Figure 1 The spread of Agriculture Supported by Communities in Europe between 1978-2015
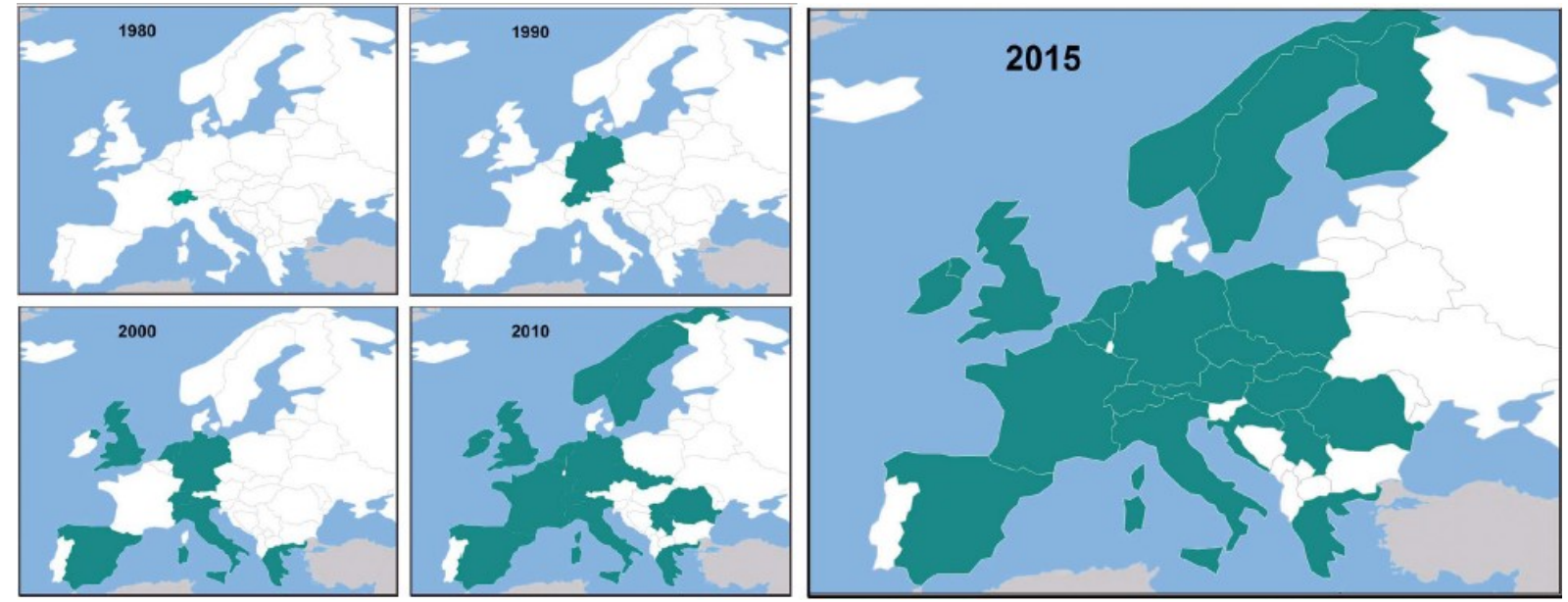

Source: Weckenbrock, Volz, , Parot, Cressot (2016, p. 9 )

According to the estimation of the European CSA research group in 2015 approximately 2 785 CSAs were operating all over Europe producing foods for about half a million consumers (474 555 people). Recently this number has been supposed to grow, but unfortunately, no updated data is available. Tab. 3 shows the estimated number of European CSAs and consumers. France can supply the majority of the farms (2000 pcs) as well as consumers (320 000 heads). At the same time, there is a considerable number of CSAs in Belgium (138 pcs), Italy (104 pcs), Germany (92 pcs), United Kingdom (80 pcs), Spain (75 pcs), Switzerland (60 pcs) and Netherlands (47 pcs). In other countries the number of CSAs spreads between 2 - 35 .

Table 3 The estimated numbers of European CSAs and consumers by countries (2015)

\begin{tabular}{|l|r|l|r|}
\hline \multicolumn{1}{|c|}{ Number of CSAs } & (number) & \multicolumn{2}{c|}{ Number of consumers (head) } \\
\hline France & 2000 & France & 320000 \\
\hline Belgium & 138 & Switzerland & 26000 \\
\hline Italy & 104 & Netherlands & 25500 \\
\hline Germany & 92 & Germany & 25000 \\
\hline United Kingdom & 80 & Italy & 22800 \\
\hline Spain & 75 & Belgium & 14500 \\
\hline Switzerland & 60 & United Kingdom & 10000 \\
\hline Netherlands & 47 & Spain & 7500 \\
\hline Norway & 35 & Norway & 6000 \\
\hline Austria & 26 & Croatia & 4000 \\
\hline Czech Republic & 23 & Greece & 2400 \\
\hline Croatia & 20 & Finland & 2000 \\
\hline Romania & 15 & Austria & 1500 \\
\hline Hungary & 12 & Czech Republic & 1400 \\
\hline Sweden & 12 & Slovakia & 1300 \\
\hline Finland & 10 & Hungary & 1200 \\
\hline Slovakia & 10 & Romania & 1000 \\
\hline Poland & 8 & Sweden & 1000 \\
\hline
\end{tabular}


Table 3 (continued)

\begin{tabular}{|l|r|l|r|}
\hline \multicolumn{1}{|c|}{ Number of CSAs } & (number) & \multicolumn{2}{c|}{ Number of consumers (head) } \\
\hline Greece & 7 & Poland & 800 \\
\hline Ireland & 7 & Ireland & 485 \\
\hline Serbia & 2 & Serbia & 70 \\
\hline Lithuania & 2 & Lithuania & 100 \\
\hline Total & $\mathbf{2 7 8 5}$ & & $\mathbf{4 7 4 5 5 5}$ \\
\hline
\end{tabular}

Source: on the basis of Weckenbrock, P.- Volz, P.- Parot, J.- Cressot, N. (2016, ps. 9, 10 ) my own edition

Near the Black Forest, in Freiburg the representatives of twelve European Countries were holding a meeting about the opportunities of co-operations of researches carried out in relation to CSAs in August, 2015. At the meeting the definition of CSA was made which all the participant were able to identify with serving as a guide the existing and future CSAs as well: "The CSA means a direct partnership between a given group of consumers and producers where all the risks, responsibilities and rewards deriving from the agricultural activities are shared according to the long-term contracts. Usually the CSA operates at a low or local level with the aim of supplying high-quality food in an agro-ecological way" (European CSA Research Group, 2016, p. 8).

According to the survey carried out in 2015 by the European CSA research group $73 \%$ of the CSA consumers hand over the ordered foods or in case of a subscription system the share of food he is entitled to at the so-called takeover points. These takeover points are usually function as public spaces near the consumers' homes or workplaces, however, in some countries there are fix takeover points in the shops of the buying communities. In these shops not only the orders can be handed over but other hand-made, local foods are available all the time. The $42 \%$ of the interviewees take over the ordered foods at the farms of the farmers, while $24 \%$ take part in the harvest and $20 \%$ of them take the opportunity of home delivery. In about half of the 22 countries there is a national network the CSA. This can be considered as quite a good rate regarding the fact that the communal agriculture appeared in some countries only some years ago. According to the survey of the international network of CSA (URGENCI=The International Network for Community Supported Agriculture) only 7\% of the interviewed European CSAs are the members of the above mentioned network. Based on the study in the analyzed countries the food distribution directly through the buying communities is typical of the following courtiers: Austria, Belgium, Hungary, Greece and Spain. In my view, if not in the strict sense, but the direct selling forms respectively consumer-producer co-operations that do not work in a contractual way or according to a strict subscription system can be regarded as buying communities only figuratively as the consumers themselves organize their food supply systems and they have a relatively wide 
Bakos, I.

latitude regarding the quality and quantity dimensions of their purchasing. The frequency of their further orders is set according to their needs.

\section{The realization and aspects of CSA in Hungary}

After the millennium in Middle- and East - Europe the communities that produced high quality, nutritious foods also appeared reaching an ever-growing, conscious circle of consumers. Due to the fact that these communities formed in a different way and structure from each other in time and space there is not a standard term to define the CSA, only common guidelines qualifying as the cross-sections of national definitions. According to the European research group of CSA (2016) these principles ensuring an alternative attitude to agriculture based on solidarity, direct human relationships, mutual respect, small-scale foodproduction and consumption respectively the respect of the environment.

In Hungary there is relatively little scientific literature on the topic of CSA consequently the standard definition has not been formed yet. The term of CSA and the English definition first appeared in the 1990s and mostly its loan translation was used by the authors. As the above mentioned term seemed too long and difficult to say the Conscious Buyers' Association (the Hungarian TVE) introduced shorter expressions in its programs as of 2008 and its professional materials such as "communal agriculture" or simply "communal farming". Réthy and Dezsény (2013) has drawn the attention to the fact that this simplification results in the change of the meaning as well. As a result, it should always be precisely defined what kind of farming and selling types are meant by a given nomination. The authors have also mentioned the definitions of "producer-consumer communities (in Hungarian TFK) as well as that of "vegetable community" used by farmers and the so - called nominations of "AMAP farmland" on the basis of French antecedents.

The systems of Community Supported Agriculture are in the beginning phase of development in Hungary. The TVE has a lion share in the popularization of CSAs and buying communities. On its web page and in its magazines it regularly publishes informative articles on the systems of communities, respectively it organizes thematic programs and through the project partners it promotes the spreading of them. For example, in co-operation with the Swiss partner Agridea they held lectures and workshops with the aim of promotion in more Hungarian and Swiss cities in the spring of 2013 under the frame of a common project. They supplied information to the inquiring audience on the CSA giving practical advice to the farmers as well. In the frame of the program the French Institute in Budapest hosted the first lecture. (Nagy, 2013). Similarly to the TVE, the Ecological Agricultural Research Center (ÖMKI) along with the involvement of ESSRG researchers of Szent István University play an important role in the popularization of CSAs with its programs and forums to the inquiring 
farmers (Réthy-Dezsény, 2013). These conferences mainly help the farmers interested in CSA or being experienced in communal farming respectively consumers can get to know each other's activities and they have the opportunity to share their ideas. The conference series of Grundtvig realized in the frame of lifetime learning program of the EU was a similar one also hosted by the French Institute in Hungary. The series of programs was held in five countries. Hungary, England, Austria, France and Germany. The TVE represented Hungary as a cooperating partner (Szilva, 2012).

The promotion of the local food networks is most important to sustain the food supply and distribution as well as to enforce the local selling, consequently Hungary drafted the Short Supply Chain Thematic Basic Program (REL) in its Rural Program of 2014-2020 in the frame of which 3.84 billion HUF could be spent on the formation and development of local food systems. This was a vital step in Hungary as the direct selling ensured existence and the possibility of advance planning for the Hungarian farms respectively the small-scale family businesses in an unfavorable macroeconomic condition. These farms mainly do ecological farming based on personal relationships and confidence contributing to the change of the consumers' attitude. (Réthy-Dezsény, 2013). The system of CSA provides a most environmentally friendly solution as it reduces the emission of harmful things accompanying the packing and delivery to the minimum. Furthermore, it saves the fields as the majority of CSA farmers fail to use herbicides, fertilizers or other chemicals. It is important to mention that the prices of these foods are much lower than that of the bio products in the shops enforcing the local economy and identity respectively as a multiplicative effect of them they contribute to the survival and sustainability of rural spaces.

The beginning phase of the system of CSA was in 1998 in Hungary with the involvement of the Institute of Environmental and Rural Farming respectively the Bio gardening workshop of the University led by Matthew Hayes in Babatvölgy (Gödöllö). The farm was named as Open Garden continuing its producing and selling activity until 2002. Some 10 years had to go by and as a result of the visit of the French AMAP farmers organized by the TVE the communal agriculture appeared in Hungary again on the initiative of some enthusiastic and talented bio farmers. In the past four years the number of farms based on communities has grown slowly and due to the increasing producer and consumer inquiry this number may multiply in the future (Réthy-Dezsény, 2013).

\section{Buying communities}

The buying communities are committed to the popularization of local foods, to the support of local farmers as well as to the sustainable food consumption. At present the buying communities are in their infancy in Hungary but they have a lot of latent potency to stimulate 
the local economy. According to the data base of January 2016 of the Association of TVE there are 12 buying communities all over the country (Tab. 4). This is supposed to be an estimated number and there may be a lot of similar initiatives in Hungary but from the aspect of the study I consider the communities as relevant that organize their activities consciously and are available for a wider circle of people by demonstrating themselves online (for example, their own web side, Facebook). I have decided to focus on these buying communities because they are supposed to have a food-distributing and delivering system as well as experience the good practices of which are to be applied in my elaboration of the sample model of the Hungarian buying communities.

Table 4 Buying communities in Hungary

\begin{tabular}{|c|c|c|}
\hline Name & Distributor points & What is on sale? \\
\hline $\begin{array}{c}\text { Bajai Szatyor } \\
\text { Közösség (Batyor) }\end{array}$ & Baja & $\begin{array}{l}\text { vegetables, fruits, dairy products, } \\
\text { smoked meat, corns, natural } \\
\text { cosmetics, herbs, drinks, syrups, } \\
\text { local hand-made products }\end{array}$ \\
\hline Borsodi Kosár Kör & Miskolc & vegetables \\
\hline Csömöri Éléskamra & Csömör & $\begin{array}{l}\text { honey, dairy products, eggs, cheese, } \\
\text { pasta, oils, vegetable, juices, jams, } \\
\text { syrups }\end{array}$ \\
\hline $\begin{array}{l}\text { Félegyházi Szatyor } \\
\text { Klub }\end{array}$ & Kiskunfélegyháza & vegetables \\
\hline Kecskeméti Szatyor & Kecskemét & $\begin{array}{l}\text { vegetables, fruits, bread, honey, jams, } \\
\text { syrups, cleaning products, cosmetics, } \\
\text { cured products, sandwich creams, } \\
\text { herbs, spices, drinks, meat products, } \\
\text { seeds, corns, oily seeds }\end{array}$ \\
\hline $\begin{array}{l}\text { Kiskosár Bevásárló } \\
\text { Közösség }\end{array}$ & Esztergom & $\begin{array}{l}\text { vegetables, fruits, dairy products, } \\
\text { bakery products, honeys, jams, tinned } \\
\text { fruits, spreads, drinks, meats, other } \\
\text { products }\end{array}$ \\
\hline $\begin{array}{l}\text { Miskolci Zöld Kosár } \\
\text { Közösség }\end{array}$ & Miskolc & $\begin{array}{l}\text { bio vegetables and fruits, different } \\
\text { kinds of local and hand-made } \\
\text { products, eco cleaning products, } \\
\text { reform cakes, gifts made by recycling } \\
\text { processes, etc,. }\end{array}$ \\
\hline Natúr kosár & Érd & fruits, vegetables \\
\hline $\begin{array}{l}\text { Nyíregyházi Kosár } \\
\text { Közösség }\end{array}$ & Nyíregyháza & $\begin{array}{l}\text { vegetables, fruits, herbs, seeds, } \\
\text { pickles, jams, honey, meats, drinks, } \\
\text { dairy products, cleaning products, } \\
\text { cosmetics }\end{array}$ \\
\hline Szatyor Bolt & Budapest & $\begin{array}{l}\text { vegetables, fruits, eggs, bakery } \\
\text { products, dairy products, meat } \\
\text { products, drinks, cosmetics }\end{array}$ \\
\hline Szatyor-Debrecen & Debrecen & $\begin{array}{l}\text { vegetables, fruits, bakery products, } \\
\text { honeys, oils, cheeses, long-lasting } \\
\text { foods }\end{array}$ \\
\hline $\begin{array}{c}\text { Szigetközi Szatyor } \\
\text { Közösség }\end{array}$ & Mosonmagyaróvár & $\begin{array}{c}\text { vegetables, fruits, syrups, jams, } \\
\text { honey }\end{array}$ \\
\hline
\end{tabular}

Source: based on TVE (2016), my own edition 
According to the registration of TVE the buying communities are mainly specialized in the distribution of vegetables and fruits, however, but there are groups (baskets) distributing a wider choice of products and not only raw ingredients but processed foods as well as local hand-made products such as Bajai Szatyor Közösség (Batyor), Csömöri Éléskamra, Kecskeméti Szatyor, Miskolci Zöld Kosár Közösség, Nyiregyházi Kosár Közösség, SzatyorDebrecen, Sziegtközi Szatyor Közösség.

In the event of buying communities the members have the widest range of choice since they are not obliged to pay in advance or take over the their share produced by the cooperating farms as in case of the system of regular customers (communal farms) or symmetrical farms (box systems). Actually, buying communities can be regarded as the combination of the above mentioned two types of systems as the buyers, if in an informal way, commit themselves to the foods of the local farmers accepting the choice determined by the seasons but they decide how many and what kind of products they intend to buy on the basis of the list made by the basket organizers on a certain week.

This present, innovative form of short supply chain has the opportunity to develop dynamically in the present programming phase and with some help it may be an integral part of the industry of tourism as well. The buying communities provide high quality, nourishing local foods deriving from verifiable origin to the members and the customers. These communities distribute the products of farmers from a territory of 50, maximum $80 \mathrm{kms}$ at farm prices. Selling the products of the farmers of a given territory the local hand-made and mainly high quality, eco products become more available common properties. At the same time the community-building function of these communities is also significant since besides the organization of food supply and transportation these communities organize programs in the frame of which there is an opportunity for common cooking while listening to living folk music or the participants have the chance to visit the supplying farmers enjoying the time spent with other members, etc. In my view, mainly Hungarian tourists interested in the traditional, hand -made farming and food production should be involved.

These types of communities as well as the Net-bag type shops can give a realistic picture of the high quality, local foods. They could contribute to the development of the small-scale, local economy and tourism by different programs, authentic guest tables, organized visits of farmers and other programs. The local foods and various gastronomic events can affect positively the tourism performance of a particular settlement and region (Csizmadiáné et al., 2015; Bottyán, 2015; Bakos-Topa, 2016). To realize the abovementioned, effective marketing communication is required respectively an intensive connection with the participants of 
tourism, for example these shops and their programs should be recommended in the offices of Tourinform, at places of accommodation and restaurants. A mobile application available in more world languages supplying information on the location of local foods and shops would be most useful. For example, where authentic, local foods are on sale, respectively the other, related programs such as guest tables, or visiting farms, etc. Tourists should be informed about this type of application in as many ways as possible and they should be provided with it. An initiative of this kind is supposed to have been started but I have never met an application used all over the country.

Also, the symbolic space forming role of the buying communities is worth mentioning. The most common symbols as well as indirect meaning content related to the buying communities are the followings: returning to the roots, consumption of healthy and sustainable foods, environmental consciousness, Hungarian identity, belonging to a community, cultural roots, taking social roles, support of local farms, etc.

The majority of buying communities are present in the virtual space by their web pages and community pages (e.g.: http://szatyorbolt.hu/). The tourism-type services such as common cooking, film club, visiting of farmers, etc. as intensive ways of communication could also promote the local gastro-tourism.

\section{The system of regular customers (communal farms)}

In case of this type of farms the consumers join the farmers for a whole year undertaking to take over the food produced at the farms each week. They pay a flat rate for the varied, seasonal foods. The circle and amount of the given food largely depend on the season. At the beginning of summer the choice is much wider than in spring (TVE, 2016). Tab. 5 shows the 17 communal farms operating in Hungary. Similarly to the case of buying communities I worked up the data base of January, 2016 of TVE. Typically, members can access to a wide range of fruits and vegetables but other basic foods, such as meat, dairy products, eggs, breads, etc), processed and tinned foods as well as spices.

Table 5 The system of regular customers operating in Hungary (communal farms)

\begin{tabular}{|c|c|c|}
\hline Name & Where is the farm/takeover point? & What is in the box? \\
\hline Bio Pipacs & $\begin{array}{c}\text { Pusztaszer } \\
\text { Szeged }\end{array}$ & vegetable \\
\hline Biofaló & $\begin{array}{c}\text { More qualified farms } \\
\text { Some districts of Budapest and Isaszeg }\end{array}$ & vegetables, fruits \\
\hline
\end{tabular}


Table 5 (continued)

\begin{tabular}{|c|c|c|}
\hline $\begin{array}{c}\text { Biokert, } \\
\text { Szigetmonostor }\end{array}$ & $\begin{array}{c}\text { Szigetmonostor } \\
\text { Óbuda, Szigetmonostor, Pomáz, Szentendre } \\
\text { Dunakeszi } \\
\text { Csillaghegy }\end{array}$ & vegetables, fruits \\
\hline Birs Közösség & $\begin{array}{l}\text { Kunszállás } \\
\text { Budapest }\end{array}$ & vegetables, fruits \\
\hline Cékla Klub & Tata, Győr, Komárom & $\begin{array}{l}\text { vegetables, fruits, spices } \\
\text { and processed products }\end{array}$ \\
\hline $\begin{array}{l}\text { Dunabogdányi } \\
\text { Tölgyes Ökofarm }\end{array}$ & $\begin{array}{c}\text { Dunabogdány } \\
\text { Szentendre, Óbuda }\end{array}$ & vegetables \\
\hline $\begin{array}{c}\text { Dunaszigeti } \\
\text { ZöldségKözösség }\end{array}$ & $\begin{array}{c}\text { Dunasziget } \\
\text { Mosonmagyaróvár }\end{array}$ & vegetables, spices \\
\hline $\begin{array}{l}\text { Eleven Föld } \\
\text { Szociális } \\
\text { Szövetkezet }\end{array}$ & $\begin{array}{c}\text { The agglomeration of Miskolc, } \\
\text { Miskolc }\end{array}$ & $\begin{array}{l}\text { vegetables, dairy } \\
\text { products, long-lasting } \\
\text { products, soaps }\end{array}$ \\
\hline Évkerék Ökotanya & $\begin{array}{l}\text { Balástya-Kistelek } \\
\text { Szeged }\end{array}$ & vegetables, spices, fruits \\
\hline Háromkaptár & $\begin{array}{c}\text { Tahitótfalu } \\
\text { Vác } \\
\text { Szentendre } \\
\text { Budapest } \\
\text { Pilisszentlászló }\end{array}$ & $\begin{array}{l}\text { vegetables, eggs, spices, } \\
\text { seeds, breads }\end{array}$ \\
\hline $\begin{array}{l}\text { MagosVölgy } \\
\text { Ökológiai } \\
\text { Gazdaság }\end{array}$ & $\begin{array}{c}\text { Terény } \\
\text { Some districts of Budapest }\end{array}$ & $\begin{array}{c}\text { vegetables, occasionally } \\
\text { processed products, jams, } \\
\text { nuts, syrups }\end{array}$ \\
\hline $\begin{array}{l}\text { Ökotársulás } \\
\text { Közösség }\end{array}$ & $\begin{array}{c}\text { Herencsény } \\
\text { Some districts of Budapest }\end{array}$ & vegetables, fruits \\
\hline $\begin{array}{l}\text { Pásztortáska } \\
\text { Baráti Kör }\end{array}$ & Debrecen & $\begin{array}{l}\text { vegetables and other bio } \\
\text { products, (oil, flour, seeds, } \\
\text { bread, bakery products, } \\
\text { creams)) }\end{array}$ \\
\hline $\begin{array}{c}\text { Pomázi Közösségi } \\
\text { Életkert }\end{array}$ & Pomáz & vegetables, mushrooms \\
\hline $\begin{array}{c}\text { Táncoskert } \\
\text { Biogazdaság }\end{array}$ & Polgár, Budapest, Nyíregyháza & eggs, meats \\
\hline Virágos tanya & $\begin{array}{c}\text { Ásotthalom, } \\
\text { Szeged, Budapest }\end{array}$ & $\begin{array}{l}\text { vegetables, fruits, eggs, } \\
\text { jams }\end{array}$ \\
\hline $\begin{array}{l}\text { Virágoskert } \\
\text { Zöldségközösség }\end{array}$ & Székesfehérvár & seasonal vegetables, eggs \\
\hline
\end{tabular}

Source: based on TVE (2016), my own edition

\section{Symmetrical farming (box-system)}

In fact, symmetrical farms operate on the basis of the communal farms, widely known as box systems. In this case buyers can obtain products at a fix price but they have the opportunity to order the box weekly or not (TVE, 2016).

According to the registration of January, 2016 of TVE there are four box systems in Hungary specialized mainly in vegetables (Tab. 6). In the "Cargonomia" box system the weekly boxes contain producer wines as well. 
Bakos, I.

Table 6 Symmetrical farms operating in Hungary (box systems)

\begin{tabular}{|c|c|c|}
\hline Name & Where is the farm/takeover point? & What is in the box? \\
\hline $\begin{array}{l}\text { Átalakuló } \\
\text { Dunapart }\end{array}$ & Zsámbok, Budapest, Pesterzsébet & vegetables \\
\hline $\begin{array}{l}\text { Átalakuló } \\
\text { Wekerle- } \\
\text { Mikosarunk }\end{array}$ & Gödöllő, Budapest, Wekerle & vegetables \\
\hline Cargonomia & $\begin{array}{l}\text { Zsámbok, } \\
\text { Kispest, Bp. VII.district, Kelenföld, Óbuda, } \\
\text { Gödöllö, Albertfalva and bicycle home delivery }\end{array}$ & vegetables, wine \\
\hline $\begin{array}{c}\text { Kelenföldi } \\
\text { Zöldségkör }\end{array}$ & Zsámbok, Budapest, Kelenföld & vegetables \\
\hline
\end{tabular}

Source: based on TVE (2016), my own edition

\section{Results of the questionnaire survey}

From the sample, for $42.8 \%$ of the respondents it was very important and for $33.9 \%$ of them it was important to have the opportunity to buy locally produced and processed foodstuffs (Fig. 2). From the demographic characteristics the gender $\left(\chi^{2}=24.304 ; \mathrm{df}=3 ; \mathrm{p}=0,000\right.$; Cramer's $\mathrm{V}=0.173)$, the school qualification $(\chi 2=50,002 ; \mathrm{df}=12 ; \mathrm{p}=0.000 ; \mathrm{Eta}=0.154)$ and the occupation $\left(\chi^{2}=81.470 ; \mathrm{df}=27 ; \mathrm{p}=0,000 ; \mathrm{Cramer}^{\prime} \mathrm{V}=0.183\right)$ indicated a significant but weak correlation with the importance of availability of local food.

In spite of my prediction, the perception of local food is unrelated to the income situation of the respondents. Responses suggest that women are more committed to local food than men, as $82.5 \%$ consider it important for local foods to be accessible to consumers. By contrast, $32.4 \%$ of men do not consider this important at all.

Respondents with higher qualifications indicated higher demand for local food $(85.6 \%)$. $40.6 \%$ of young students do not consider local food important at all, which is saddening, because in a few years they will be the largest part of the demand for food. For people staying at home with children it was important to buy high-value, healthy, traceable food, similarly to housewives, from whom $91.7 \%$ said the same. 
Figure 2 The importance of buying locally produced food (\%)

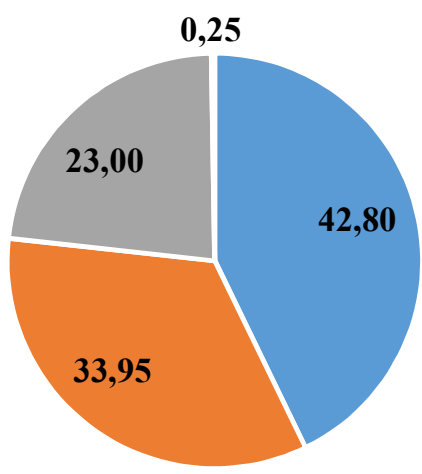

- I consider it very important $\quad$ I consider it partly important
$\square$ I do not consider it important at all $₫ \mathrm{I}$ do not know / I do not answer

Source: Own questionnaire survey $(2016-2017, \mathrm{n}=817)$

Based on the results of the cross-table analysis (Tab. 7), we can see, which are the most important aspects when buying food for the locals interested in local food products.

Table 7 Food buying profile of people preferring local food (\%)

\begin{tabular}{|c|c|c|c|c|c|c|c|}
\hline \multirow[t]{2}{*}{ Factors } & \multicolumn{6}{|c|}{$\begin{array}{l}\text { During buying food, how important are } \\
\text { the following factors to you on a scale } \\
\text { from } 1 \text { to } 6 \text {, where } 1=\text { not important at all, } \\
\text { and } 6=\text { very important }\end{array}$} & \multirow[t]{2}{*}{ Correlation } \\
\hline & 1 & 2 & 3 & 4 & 5 & 6 & \\
\hline The fame of the grocery & 7.8 & 5.8 & 13.0 & 21.6 & 25.1 & 26.8 & $\begin{array}{l}\text { Weak relationship: } \\
\chi 2=34.344 ; \quad \mathrm{df}=15 ; \\
\mathrm{p}=0.03 ; \text { Eta }=0.160\end{array}$ \\
\hline $\begin{array}{l}\text { Everything should be available in one } \\
\text { place }\end{array}$ & 2.3 & 6.3 & 12.1 & 19.5 & 34.5 & 25.3 & None \\
\hline The Hungarian origin of the product & 1.7 & 1.1 & 5.7 & 14.1 & 31.3 & 46.0 & $\begin{array}{l}\text { Strong relationship: } \\
\chi 2=224.956 ; \quad \mathrm{df}=15 ; \\
\mathrm{p}=0.000 ; \mathrm{Eta}=0.480\end{array}$ \\
\hline Locally produced food & 1.7 & 2.0 & 10.3 & 17.2 & 35.6 & 33.0 & $\begin{array}{l}\text { Strong relationship: } \\
\chi 2=403.422 ; \quad \mathrm{df}=15 ; \\
\mathrm{p}=0.000 ; \mathrm{Eta}=0.617\end{array}$ \\
\hline If the product is from an organic farm & 5.5 & 12.6 & 18.7 & 20.7 & 23.3 & 19.3 & $\begin{array}{l}\text { Moderate } \\
\text { relationship: } \\
\chi 2=105.896 ; \quad \mathrm{df}=15 ; \\
\mathrm{p}=0.000 ; \mathrm{Eta}=0.300\end{array}$ \\
\hline $\begin{array}{l}\text { The fame of the brand of the food } \\
\text { product }\end{array}$ & 6.0 & 9.2 & 17.8 & 27.6 & 24.4 & 14.9 & None \\
\hline Price & 3.7 & 2.9 & 6.0 & 20.1 & 27.3 & 39.9 & None \\
\hline Quality & 0.3 & 0.6 & 0.9 & 4.6 & 24.7 & 69.0 & $\begin{array}{l}\text { Weak relationship: } \\
\chi 2=28.831 ; \quad \mathrm{df}=15 ; \\
\mathrm{p}=0.017 ; \mathrm{Eta}=0.174\end{array}$ \\
\hline Environment-friendly packaging & 2.3 & 8.6 & 14.1 & 22.1 & 21.6 & 31.3 & $\begin{array}{l}\text { Moderate } \\
\text { relationship: } \\
\chi 2=111.690 ; \quad \mathrm{df}=15 ; \\
\mathrm{p}=0.000 ; \mathrm{Eta}=0.326\end{array}$ \\
\hline Health-consciousness & 1.1 & 1.4 & 5.7 & 14.9 & 37.4 & 39.4 & $\begin{array}{l}\text { Moderate } \\
\text { relationship: } \\
\chi 2=125.894 ; \quad \mathrm{df}=15 ; \\
\mathrm{p}=0.000 ; \mathrm{Eta}=0.351\end{array}$ \\
\hline $\begin{array}{l}\text { The recommendation of family, } \\
\text { friends }\end{array}$ & 4.9 & 5.7 & 14.4 & 22.4 & 30.2 & 22.4 & $\begin{array}{l}\text { Weak relationship: } \\
\chi 2=54.254 ; \quad \mathrm{df}=15 ; \\
\mathrm{p}=0.000 ; \mathrm{Eta}=0.189\end{array}$ \\
\hline
\end{tabular}


Source: Own questionnaire survey and calculation $(2016-2017, \mathrm{n}=817)$

However, the most important characteristic of their food buying habits is probably the awareness. $33.99 \%$ of the respondents consider it very important, while $51.60 \%$ of them consider it at least important to have a grocery store in their area, where only local and Hungarian food products would be available (Fig. 3). There is a considerable demand for local food, however, only $11.03 \%$ of the people are members of shopping communities in the settlement, and only $30.27 \%$ of them have heard of this initiative, but have never purchased food there. $58.7 \%$ of respondents have never heard of shopping communities. The highest number of people among the respondents who knew about these communities lives in Csömör and Esztergom. This is probably due to the fact that Csömör is a small town of 8,723 people where the fame of such a community is spreading more easily. Among the shopping communities in the settlements investigated, Esztergom performs intense online marketing activities, and its positive impact was supported by the results of the questionnaire.

Figure 3 How important would it be for you to have groceries in your town where only local and Hungarian food producers would be available? (\%)

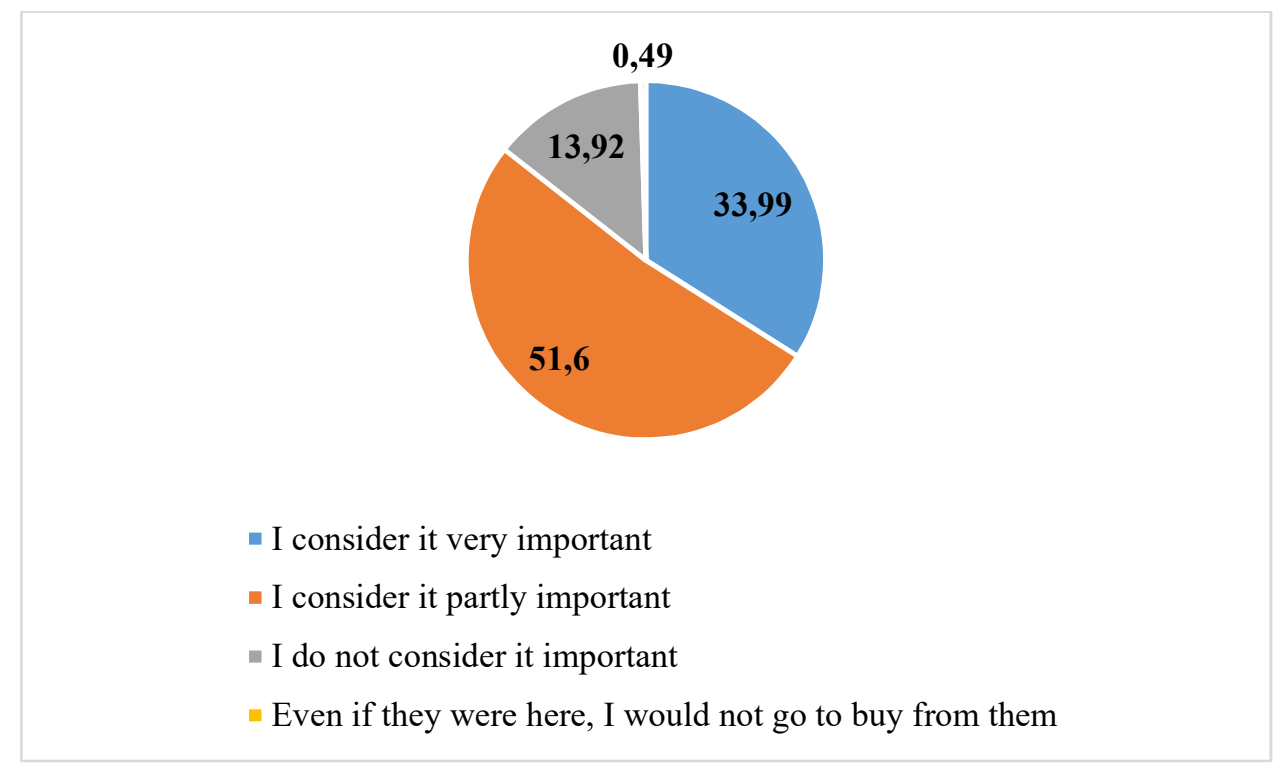

Source: Own questionnaire $(2016-2017, \mathrm{n}=817)$

There is usually an NGO behind shopping communities, and most of them face resource shortages and infrastructure problems, so their survival and development largely depends on cost-effective online communication. $33.95 \%$ of the respondents would be willing to pay more for local food, while $38.73 \%$ of them would pay more only for a few basic foods. Tab. 8 illustrates the most common channels the respondents use to purchase food products. In the case of meat products and bakery products, retail shops are still popular sources, and the case is similar for the market for vegetables and fruits, eggs and pickles. Regardless of the type of 
settlement, the Hungarian households surveyed still have pickling, as well as jam and compote making.

Table 8 The places of purchasing food products for the respondents (\%)

\begin{tabular}{|l|r|r|r|r|r|r|r|}
\hline \multicolumn{1}{|c|}{$\begin{array}{c}\text { Place of } \\
\text { purchase }\end{array}$} & $\begin{array}{l}\text { Meat } \\
\text { products }\end{array}$ & $\begin{array}{r}\text { Fruit and } \\
\text { vegetables }\end{array}$ & $\begin{array}{c}\text { Bakery } \\
\text { products }\end{array}$ & \multicolumn{1}{c|}{$\begin{array}{c}\text { Dairy } \\
\text { products }\end{array}$} & Pickles & $\begin{array}{c}\text { Marmalades, } \\
\text { honey, other } \\
\text { jarred } \\
\text { products }\end{array}$ & Egg \\
\hline Hypermarket & 18.5 & 10.5 & 10.7 & $\mathbf{2 3 . 4}$ & 15.4 & 10.6 & 11.1 \\
\hline Supermarket & 16.9 & 13.0 & 12.9 & $\mathbf{2 9 . 8}$ & 17.0 & 12.4 & 13.6 \\
\hline $\begin{array}{l}\text { Local } \\
\text { grocery }\end{array}$ & 12.8 & 11.5 & 29.3 & $\mathbf{2 8 . 5}$ & 10.7 & 9.8 & 14.5 \\
\hline Market & 10.3 & $\mathbf{3 7 . 1}$ & 2.3 & 6.8 & $\mathbf{2 5 . 5}$ & 13.2 & $\mathbf{2 7 . 1}$ \\
\hline Retail shop & $\mathbf{3 5 . 7}$ & 16.9 & $\mathbf{4 0 . 4}$ & 7.2 & 8.4 & 3.7 & 5.3 \\
\hline $\begin{array}{l}\text { Buying } \\
\text { group }\end{array}$ & 0.5 & 1.4 & 0.7 & 2.2 & 1.3 & 2.7 & 2.5 \\
\hline $\begin{array}{l}\text { Homemade } \\
\text { product }\end{array}$ & 5.3 & 9.5 & 3.8 & 2.2 & $\mathbf{2 1 . 8}$ & $\mathbf{4 7 . 7}$ & $\mathbf{2 5 . 9}$ \\
\hline
\end{tabular}

Source: Own questionnaire $(2016-2017, \mathrm{n}=817)$

Based on the calculations of the Hungarian Central Statistical Office in 2014, the increase in income results in the decrease of the number of purchased and self-produced foods decreases, while the proportion eating at the workplace, at school and at restaurants increases. In the case of the top income quintile, nearly three quarters of food expenditure for its households is made up by purchased food, only $3.0 \%$ of their own production and about $23 \%$ of out-ofhome meals. It is also remarkable that in 2014 the structure of the food consumption of the lower income categories has changed favorably; on comparative prices, the expenditure on purchased and out-of-dining meals increased more rapidly than for those who have better income levels and this resulted more favorable expenditure rates for their food in the year 2013.

\section{CONCLUSION}

Due to the industrialization of agriculture as well as the globalization of food trade the smallscale agricultural production and consumption supporting local products have been neglected all over the world. Global food chains are squeezing out and prevailing over local farmers resulting in unequal power relations that generate significant social tension in the world putting a strain on the environment. Recognizing it in several countries of the world the governments and conscious consumers make efforts to form local food networks and to maintain them. The agricultural systems supported by the communities supply an indirect way of alternative selling channels with maximum one mediator for the food producing little farms that have been neglected by reason of the global competition. These innovative selling 
channels forms from below can bring producers and end-consumers closer to each other contributing to the direct marketization of high quality, nourishing foods and to the development of local economy as well as tourism.

The systems of CSA in their present form are not able to compete with and to substitute for the industrial food supply chains, nevertheless, they do not even aim to do that as they can operate only parallely to these systems completing them. The aim is to demonstrate that it is possible and required to move to a socially, environmentally and culturally more sustainable direction. I am convinced that a certain level of self-sufficiency is coded in the local communities that can be revived and stimulated by a suitable supporting community and its function activating the "local heroes" who take an active role in the development of local economy. The good practices that have been applied in Hungary and abroad in the past few decades based on these efforts definitely prove the reason for existence of the CSA systems.

The local food products as well as the traditional and alternative short supply chains promoting their selling (e.g. buying community-type shops) may contribute to the development of rural tourism respectively to the transmitting of local values directly or indirectly. I do hope that the European Union financial resources promoting the above mentioned channels and their participants will be used efficiently and economically in the present program period having a multiplicative effect on the local economies and tourism.

The results of the questionnaire survey could provide directions for decision-makers and local food system operators and organizers. Based on the results, women with small children and female mental workers could mean the highest demand for high-value-added and safe source food products. When compiling the marketing mix for local food systems, it is very important to create powerful online marketing and to shape their marketing mix to be attractive to a conscious, but modern consumer segment.

On the policy side, besides the European Union and domestic financial resources, the importance of small-scale food production and consumption should also be promoted by other means, which could bring the countryside and the city closer together, directly and indirectly as well, and contribute to the development of local communities and could support those not able to compete on the global market. This popularizing and awareness-raising activity would be especially important among young people, since the results of the questionnaire showed that young people do not prefer local food.

This generation has been born into the world of multinational companies, and most of them are not familiar with the flavor and feeling of rural, healthy foods. There are efforts by the government to feed local and organic food into canteens and buffets, but I believe that even 
more efforts are needed to raise the awareness of young people, because they will determine food demand in a few years. The positive effects of local and organic food consumption, such as health, environmental, social and economic impacts should be promoted among young people.

\section{Acknowledgement}

This study was Supported by the ÚNKP-16-3-I. New National Excellence Program of the Ministry of Human Capacities.

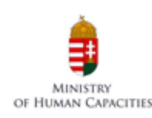

\section{REFERENCES}

Bakos I. M., Topa, Z. (2016). The Contribution of Local Food to Tourism in Hungary. Contemporary Research on Organization Management and Administration, 4(2), 63-74.

Bottyán, I. (2015). The Impact of Domestic Gastronomic Festivals on the Local Accomodations. Deturope, 7, 2: 188-205.

Csizmadiáné Czuppon, V., Csajka, S.E. Molnár, T. (2015). Potentials of Local Economic Development in Aspect of Tourism. Deturope, 7, 2: 175-187.

Cooley, J. P., Lass, D. A. (1998). Consumer benefits from community supported agriculture membership. Review of Agricultural Economics, 20(1), 227-237.

DeLind, L. B. (1999). Close encounters with a CSA: the reflections of a bruised and somewhat wiser anthropologist. Agriculture and Human Values, 16, 3-9. Retrieved October 20, 2016, from https://www.scopus.com/record/display.uri?eid=2-s2.00001926506\& origin=inward\&txGid=9CFAF0D0E74DCF4F58F7653B93BA76EE.wsn Aw8kcdt7IPYLO0V48gA\%3a1

Henderson, E. (2010). Community Supported Foods and Farming. Keynote for Urgenci Kobe Conference 2010 February 22nd. Retrieved December 8, 2016, from http://urgenci.net/csa-history/

European Committee (2007). The order of the Council nr. 834/2007/EK on ecological farming and labelling of ecological products respectively the repeal of order $\mathrm{nr}$. 2092/91/EGK. Retrieved August 4, 2016, from http://www.biokontroll.hu/cms/images/downloads/jogszabalyok/Tanacs_834-2007-EKrendelete.pdf

European CSA Research Group (2016). Overview of Community Supported Agriculture in Europe. Retrieved June 18, 2016, from http://urgenci.net/wpcontent/uploads/2016/05/Overview-of-Community-Supported-Agriculture-inEurope.pdf

Farm To City (n. d.). CSA's. Retrieved August 12, 2016, from http://www.farmtocity.org/MarketList.asp?view=csa

KSH (2015). Elözetes adatok a háztartások 2014. évi fogyasztásáról.. Statisztikai Tükör. 2015/25 Retrieved June 25, 2017, from http://www.ksh.hu/docs/hun/xftp/stattukor/haztfogy/haztfogyhavi1412.pdf

Lamine, C. (2005). Settling the shared uncertainties: local partnerships between producers and consumers. Sociologia Ruralis. Volume 45(4), 324-345. Retrieved November 4, 2016, from http://onlinelibrary.wiley.com/doi/10.1111/j.1467-9523.2005.00308.x/abstract

Parot, J. (2015). Amap, the French CSA Model: Business as usual or Social Movement? International Network Urgenci, Aubaugne. Retrieved November 5, 2016, from http://urgenci.net/wp-content/uploads/2015/02/PAROT_CASS_ARTICLE_2015.pdf 
Mariola, M. J. (2008). The local industrial complex? Questioning the link between local foods and energy use. Agriculture and Human Values. 25(2), 193-196. Retrieved November 4, 2016, from http://link.springer.com/article/10.1007\%2Fs10460-008-9115-3

Nagy, M. (2013). Communal agriculture: examples from Europe and Hungary. Retrieved January 12, 2016, from http://tudatosvasarlo.hu/cikk/kozossegi-mezogazdasag-peldakeuropabol-es-itthonrol.

Perényi, Zs., Horváth, G. (2009). Questions and answers about the operation of the French AMAP groups. TVE. Retrieved September 3, 2016, from http://tudatosvasarlo.hu/attachment/file/105/AMAP_FAQ.pdf

Réthy, K., Dezsény, Z. (2013). Agriculture supported by communities. Guide for farmers about short food chains and the forming of producing-consuming communities. Ecological - Agricultural Research Centre Press. Retrieved September 18, 2016 from http://orgprints.org/26263/1/kozosseg_altal_tamogatott_mezogazdasag.pdf

Sajtos, L., Mitev, A. (2007). SPSS kutatási és adatelemzési kézikönyv. Alinea Kiadó.

Szilva, E. (2012). Buying from farmers: everybody does in a different way. Retrieved August 10, 2016, from http://tudatosvasarlo.hu/cikk/vasarlas-gazdaktol-mindenki-maskeppcsinalja

Association of Conscious Buyers (2016). Communal farming. Retrieved August 18, 2016, from http://tudatosvasarlo.hu/csa

Weckenbrock, P., Volz, P., Parot, J., Cressot, N. (2016). Introduction to Community Supported Agriculture in Europe. In. European CSA Research Group (2016). Overview of Community Supported Agriculture in Europe. Retrieved June 18, 2016, from http://urgenci.net/wp-content/uploads/2016/05/Overview-of-Community-SupportedAgriculture-in-Europe.pdf 